\title{
Detection of porcine circovirus type 1 in commercial porcine vaccines by loop-mediated isothermal amplification
}

\author{
Chun Wang • Victor Fei Pang • Chian-Ren Jeng • \\ Fan Lee • Yu-Wen Huang • Yeou-Liang Lin • \\ Shih-Hsuan Hsiao • Shiow-Suey Lai
}

Received: 17 May 2011 / Accepted: 1 September 2011 /Published online: 27 September 2011

(C) The Author(s) 2011. This article is published with open access at Springerlink.com

\begin{abstract}
A loop-mediated isothermal amplification (LAMP) method with a real-time monitoring system was developed for the detection of porcine circovirus type 1 (PCV1) in commercial swine vaccines. This method was highly specific for PCV1. No cross-reaction to porcine circovirus type 2 , porcine parvovirus, pseudorabies virus, classical swine fever virus, and porcine reproductive and respiratory syndrome virus was observed. The analytical sensitivity of the LAMP for PCV1 DNA was 10 copies/ $\mu 1$ in the case of positive recombinant plasmid comparable to that obtained from the nested polymerase chain reaction (nested PCR). Furthermore, 25 commercial swine vaccines were tested by both the LAMP and the nested PCR, and three of them were tested positive for PCV1 DNA. These results indicate that PCV1 DNA can be real-time detected by the LAMP; the method was highly specific, sensitive, and rapid for the detection of PCV1 DNA, particularly in commercial swine vaccines.
\end{abstract}

\section{Abbreviations \\ PCV1 Porcine circovirus type 1 \\ PCV2 Porcine circovirus type 2}

C. Wang $\cdot$ F. Lee $\cdot$ Y.-W. Huang $\cdot$ Y.-L. Lin

Animal Health Research Institute, Council of Agriculture, Executive Yuan,

No. 376, Chung-Cheng Road, Tansui,

New Taipei City 25158, Taiwan

C. Wang $\cdot$ V. F. Pang $\cdot$ C.-R. Jeng $\cdot$ Y.-W. Huang $\cdot$ S.-H. Hsiao $•$

S.-S. Lai $(\bowtie)$

School of Veterinary Medicine, National Taiwan University,

No. 1, Sec. 4, Roosevelt Road,

Taipei 10617, Taiwan

e-mail: lai@ntu.edu.tw

S.-S. Lai

e-mail: fz750@ms19.url.com.tw
PMWS Post-weaning multisystemic wasting syndrome

PDNS Porcine dermatitis and nephropathy syndrome

PCVAD Porcine circovirus associated disease

PNP Proliferative and necrotizing pneumonia

ORF Open reading frame

LAMP Loop-mediated isothermal amplification

PCR Polymerase chain reaction

PPV Porcine parvovirus

PRRSV Porcine reproductive and respiratory syndrome virus

CSFV Classic swine fever virus

PRV Pseudorabies virus

Porcine circovirus (PCV) belongs to the genus Circovirus of the family Circoviridae (Finsterbusch and Mankertz 2009). PCV is non-enveloped, $17 \mathrm{~nm}$ in size, and contains a circular single-stranded DNA genome with two major open reading frames, ORF1 and ORF2 (Finsterbusch and Mankertz 2009). ORF1 is believed to encode replicationassociated proteins (Cheung 2003; Finsterbusch et al. 2005; Mankertz et al. 2004). ORF2 encodes a major capsid protein containing immunologically important domains associated with virus neutralization (Lekcharoensuk et al. 2004; Mahé et al. 2000). PCV has been divided into two distinct clusters, PCV1 and PCV2 (An et al. 2009; Calsamiglia et al. 2002; Cságola et al. 2008; Muhling et al. 2006). PCV2 can be distinguished from PCV1 on the basis of genome sequence and antigenicity (Calsamiglia et al. 2002; Mahe et al. 2000; Muhling et al. 2006).

PCV1 has been isolated from contaminated PK-15 cells (Dulac and Afshar 1989; Tischer et al. 1995) and is not considered to be pathogenic for pigs (Allan et al. 1995; 
Tischer et al. 1986). Presence of PCV1 in domestic pigs is not surprising because a number of viral vaccines are manufactured from porcine-derived components, which may be contaminated with PCV1 (Quintana et al. 2006). Meanwhile, contamination of PCV1 in vaccine products is unacceptable, and such products should not be used in pig farms (Quintana et al. 2006). PCV2, unlike PCV1, is pathogenic to pigs and is considered as the primary causative agent of post-weaning multisystemic wasting syndrome (PMWS), porcine dermatitis and nephropathy syndrome (PDNS), porcine respiratory disease complex (PRDC), proliferative and necrotizing pneumonia (PNP), and porcine circovirus-associated disease (PCVAD) (Chae 2005; Kixmöller et al. 2008; Wang et al. 2004). Recently, the emergence of PCV2 infection has led to a significant increase in post-weaning mortality and high economic losses for the swine industry around the world (Horlen et al. 2007; Kixmöller et al. 2008).

Loop-mediated isothermal amplification (LAMP) is an excellent diagnostic tool for detecting specific nucleic acid sequences in clinical samples (Alhassan et al. 2007; Chen et al. 2008; de Castro et al. 2008; Han et al. 2007; Notomi et al. 2000). This technique is highly specific, relatively fast, and easy to perform. In the LAMP reaction, a DNA sample is incubated with specific LAMP primer sets, Bst DNA polymerase with strand-displacement activity, and substrates at a constant temperature between $60^{\circ} \mathrm{C}$ and $65^{\circ} \mathrm{C}$ (Alhassan et al. 2007; Chen et al. 2008; Ihira et al. 2004; Nagashima et al. 2007). The LAMP has been used successfully to detect PCV2 in field samples (Chen et al. 2008), but has not yet been developed to detect PCV1 in commercial swine vaccines. The aim of this study was to develop a LAMP with a real-time monitoring system for the detection of PCV1 in commercial swine vaccines.

\section{Materials and methods}

Commercial porcine vaccines and viruses A total of 25 commercially available porcine vaccines were obtained from licensed manufacturers and pharmaceutical suppliers in Taiwan (Table 1). Viral DNA was extracted from each vaccine using the QIAamp DNA Extraction Kit (Qiagen, USA) according to the manufacturer's instructions. For evaluating specificity of the LAMP, 21 virus isolates, comprising six PCV1, five PCV2, two porcine parvovirus (PPV), three pseudorabies virus (PRV), three classic swine fever virus (CSFV), and two porcine reproductive and respiratory syndrome virus (PRRSV) isolates, were used; all of the isolates were previously identified by determining their partial nucleotide sequences (Wang et al. 2004, 2008; Huang et al. 2009). The DNA of PCV1, PCV2, PPV, PRV, and cDNA of CSFV and PRRSV isolates were produced as described previously (Huang et al. 2009; Wang et al. 2004, 2008)

Primers Specific primer sets of the LAMP for PCV1 detection were designed by PrimerExplorer V4 software (http://primerexplorer.jp/elamp4.0.0/index.html) based on different reference PCV1 isolates (GenBank accession no. AF012107, AY184287, AY219836, AY660574, DQ472013, DQ659154, EF493843, FJ475129, and GU722334). The primer sets consisted of two outer primers (F3 and B3) and two inner primers (FIP and BIP) targeting a conserved region within the PCV1 ORF2 gene. To further validate the LAMP, the primers PCV-F1, PCV-R1, PCV-F2, and PCV-R2 were used for nested polymerase chain reaction (nested PCR) targeting the conserved region of the PCV1 ORF2 gene (Victoria et al. 2010). Nucleotide sequences and locations of the primers are shown in Table 2.

LAMP reaction A $25-\mu 1$ reaction mixture consisted of $12.5 \mu \mathrm{l}$ of $2 \times$ LAMP reaction buffer (Eiken Chemical, Japan), 8 U Bst DNA polymerase (New England Biolabs, USA), $2 \mu \mathrm{l}$ of the extracted target DNA sample, $40 \mathrm{pmol}$ each of FIP and BIP primers, and 5 pmol each of F3 and B3 primers. The LAMP reaction was conducted by incubating the reaction mixture at $60^{\circ} \mathrm{C}$ for $60 \mathrm{~min}$ and then inactivating the Bst DNA polymerase at $80^{\circ} \mathrm{C}$ for $2 \mathrm{~min}$. The reaction was monitored in real-time at 6 -s intervals by measuring the turbidity at $\mathrm{A}_{650}$ using a Loopamp real-time turbidimeter (LA-320; Eiken Chemical, Japan). The cutoff turbidity was set at 0.1 turbidity units and was determined by analyzing negative controls in replicates. A sample with turbidity remaining below 0.1 turbidity units throughout the 60-min incubation period was considered to be negative for PCV1 DNA. If the turbidity of a sample increased above 0.1 turbidity units within the 60 -min incubation period, it was considered to be positive, indicating contamination with PCV1 DNA. The LAMP amplicons were further analyzed by electrophoresis through a $2 \%$ agarose gel containing $0.5 \mathrm{mg} / \mathrm{ml}$ SYBR Safe DNA gel stain (Invitrogen, USA) in Tris-acetate-EDTA (ethylenediamine tetra-acetic acid) buffer.

Nested PCR reaction A total of 25 PCR reaction mixtures of the first round PCR in the nested PCR consisted of $2.5 \mu \mathrm{l}$ of $10 \times$ buffer $(100 \mathrm{mmol} / 1$ Tris- $\mathrm{HCl}$ at $\mathrm{pH} 8.8,500 \mathrm{mmol} /$ $1 \mathrm{KCl}, 15 \mathrm{mmol} / 1 \mathrm{MgCl}_{2}, 1 \%$ Triton X-100), $1.25 \mu \mathrm{mol} /$ 1 each of four nucleoside triphosphates, $20 \mu \mathrm{mol} / 1$ of each primer, $0.5 \mu \mathrm{l}$ of DNA polymerase POWER TAQ $(2 \mathrm{U} / \mu \mathrm{l}$; Bertec, Taipei, Taiwan), and $2 \mu \mathrm{l}$ of the DNA sample. The first round PCR was performed at $95^{\circ} \mathrm{C}$ for $5 \mathrm{~min}$, followed by 30 cycles of denaturation at $95^{\circ} \mathrm{C}$ for $20 \mathrm{~s}$, annealing at $55^{\circ} \mathrm{C}$ for $30 \mathrm{~s}$, and extension at $72^{\circ} \mathrm{C}$ for $30 \mathrm{~s}$. Finally, the 
Table 1 Detection of PCV1 DNA in commercial vaccines by the LAMP and the nested PCR

\begin{tabular}{|c|c|c|c|}
\hline Manufacturer & Agent & LAMP & $\begin{array}{l}\text { Nested } \\
\text { PCR }\end{array}$ \\
\hline A & CSFV & - & - \\
\hline A & PRV & - & - \\
\hline B & CSFV & + & + \\
\hline B & PRV & - & - \\
\hline $\mathrm{C}$ & CSFV & + & + \\
\hline $\mathrm{C}$ & $\begin{array}{l}\text { PRV, B. bronchiseptica, } P \text {. } \\
\quad \text { multocida }\end{array}$ & - & - \\
\hline $\mathrm{D}$ & CSFV & - & - \\
\hline $\mathrm{D}$ & FMDV & - & - \\
\hline $\mathrm{E}$ & CSFV & + & + \\
\hline $\mathrm{E}$ & PRV & - & - \\
\hline $\mathrm{F}$ & CSFV & - & - \\
\hline $\mathrm{F}$ & $\begin{array}{l}\text { PRV, E. rhusiopathiae, } P . \\
\quad \text { multocida, M. hyopneumoniae }\end{array}$ & - & - \\
\hline $\mathrm{F}$ & FMDV & - & - \\
\hline G & FMDV & - & - \\
\hline G & PRRSV & - & - \\
\hline $\mathrm{H}$ & FMDV & - & - \\
\hline $\mathrm{H}$ & $\begin{array}{l}\mathrm{PRV}, \text { M. hyopneumoniae, E. } \\
\text { coli }\end{array}$ & - & - \\
\hline I & PRRSV & - & - \\
\hline $\mathrm{J}$ & PPV & - & - \\
\hline $\mathrm{J}$ & FMDV & - & - \\
\hline $\mathrm{K}$ & FMDV & - & - \\
\hline $\mathrm{L}$ & PPV & - & - \\
\hline M & PRV, PPV, E. rhusiopathiae & - & - \\
\hline $\mathrm{N}$ & CSFV & - & - \\
\hline $\mathrm{N}$ & FMDV & - & - \\
\hline
\end{tabular}

$C S F V$ classic swine fever virus, $P R V$ pseudorabies virus, $F M D V$ footand-mouth disease virus, $P R R S V$ porcine reproductive and respiratory syndrome virus, $P P V$ porcine parvovirus samples were subjected to a terminal extension step at $72^{\circ} \mathrm{C}$ for $10 \mathrm{~min}$. From this reaction, $2 \mu \mathrm{l}$ of the first round PCR product was used as a template for the nested PCR. In the nested PCR, $25 \mu \mathrm{l}$ of reaction mixture consisted of $2.5 \mu \mathrm{l}$ of $10 \times$ buffer $(100 \mathrm{mmol} / 1$ Tris- $-\mathrm{HCl}$ at $\mathrm{pH} 8.8,500 \mathrm{mmol} / \mathrm{l} \mathrm{KCl}$, $15 \mathrm{mmol} / \mathrm{l} \mathrm{MgCl}_{2}, 1 \%$ Triton X-100), $1.25 \mu \mathrm{mol} / \mathrm{l}$ each of four nucleoside triphosphates, $20 \mu \mathrm{mol} / 1$ of each primer, and $0.5 \mu \mathrm{l}$ of DNA polymerase POWER TAQ ( $2 \mathrm{U} / \mu \mathrm{l}$; Bertec, Taiwan). The nested PCR was performed at $95^{\circ} \mathrm{C}$ for $5 \mathrm{~min}$, followed by 30 cycles each of denaturation at $95^{\circ} \mathrm{C}$ for $20 \mathrm{~s}$, annealing at $55^{\circ} \mathrm{C}$ for $20 \mathrm{~s}$, and extension at $72^{\circ} \mathrm{C}$ for $20 \mathrm{~s}$. Finally, the samples were subjected to a terminal extension step at $72^{\circ} \mathrm{C}$ for $10 \mathrm{~min}$. Amplicon of the nested PCR were analyzed by electrophoresis through a $2 \%$ agarose gel as described above.

Construction of recombinant plasmids Full-length ORF2 gene of PCV1 (GenBank accession no. AY219836) was amplified as described previously (Lekcharoensuk et al. 2004). The amplicon was ligated into the pCRII-TOPO plasmid that was supplied with the Dual Promoter TOPO TA Cloning Kit (Invitrogen, USA). Top10F ${ }^{\circledR}$ Escherichia coli competent cells (Invitrogen, USA) were transformed with the recombinant plasmid according to the manufacturer's instructions. The inserted target gene carried by the recombinant plasmid was directly sequenced as described previously (Wang et al. 2004). The recombinant plasmid was quantified by measuring its absorbance $A_{260}$ on a U2100 pro UV/Vis spectrophotometer (General Electronic Healthcare, Singapore) and diluted to $10^{7}$ copies/ $\mu$ lo develop a standard curve for evaluating the analytical sensitivity of the LAMP.

Analytical specificity and sensitivity of the LAMP To determine the analytical specificity of the LAMP, DNA samples extracted from the 21 virus isolates were tested by

Table 2 Oligonucleotide primer sets used for the LAMP and nested PCR

\begin{tabular}{lllll}
\hline & Primer & Position $^{\mathrm{a}}$ & Type & Sequence (5'-3') \\
\hline LAMP & F3 & $1,210-1,228$ & Forward outer & TTG TTT GGT CCA GCT CAG G \\
& B3 & $1,400-1,381$ & Backward outer & CAG AGA CCC CAT CAC CTC TA \\
& FIP & $1,289-1,271,1,230-1,248$ & Forward inner & CTC CTC CTC CCG CCA CAC CAT A \\
& & & F1c-TTTT-F2 & -TTTT - TTG GGG GTG AAG TAC CTG G \\
& BIP & $1,306-1,327,1,372-1,354$ & Backward inner & CAT AGG CCA AGT TGG TGG ACG G \\
& & & B1c-TTTT-B2 & -TTTT- GGT GTT GGG TCC ACT GTT G \\
Nested PCR & PCV-F1 & $1,146-1,167$ & First forward & TTG GTG TGG GTA TTT AAA TGG A \\
& PCV-R1 & $1,677-1,659$ & First reverse & GCA GCC ATC TTG GAA ACA T \\
& PCV-F2 & $1,297-1,318$ & Second forward & TAT AGG GGT CAT AGG CCA AGT T \\
& PCV-R2 & $1,452-1,431$ & Second reverse & CCC TAC CTT TCC AAT ACT ACC G \\
\hline
\end{tabular}

\footnotetext{
${ }^{a}$ Location of the primers based on the nucleotide sequence of the ORF2 gene of PCV1 (GenBank accession no. AY219836)
}

${ }^{\mathrm{b}}$ Both inner primers FIP and BIP contained two binding regions and were connected by a TTTT bridge 
the LAMP. DNA extracted from specific-pathogen-free (SPF) swine tissue samples was used as the negative control. To evaluate the analytical sensitivity of the assay, 10 -fold serial dilutions of the recombinant plasmid were performed to prepare the dilutions at concentration from $10^{7}$ copies $/ \mu$ l to 1 copy $/ \mu l$, and each dilution was tested by both the LAMP and the nested PCR (Victoria et al. 2010). For quantification of the diluted samples, a standard curve was generated for the LAMP, with serial 10-fold dilutions of the recombinant plasmid that were positive for PCV1 DNA on the $X$-axis and the time of positivity (min) on the $Y$-axis.

Evaluation of LAMP with commercial swine vaccines Two batches of each vaccine were tested for detection of PCV1 DNA by the LAMP and the nested PCR, respectively. To evaluate the vaccine matrices for interference or inhibition of the LAMP reaction, all extracted DNA of tested vaccine samples were spiked with plasma containing the recombinant plasmid. The final concentration of the recombinant plasmid for each spiked vaccine sample was $10^{6}$ copies $/ \mathrm{ml}$. Detection of PCV1 DNA for each spiked vaccine sample was performed by the LAMP as an internal control.

\section{Results}

The analytical specificity of LAMP was evaluated using DNA extracted from PCV1, PCV2, PPV, and PRV, and cDNA derived from CSFV and PRRSV. PCV1 DNA was successfully detected, and a ladder-like amplicon was generated (Fig. 1). The LAMP amplified the PCV1 target gene, but not the nucleic acids extracted from PCV2, PPV, PRV, CSFV, and PRRSV (Fig. 1).
By testing 10 -fold serial dilutions $\left(10^{7}\right.$ copies $/ \mu l$ to 1 copy $/ \mu \mathrm{l}$ ) of the recombinant plasmid, the LAMP demonstrated a detection limit of 10 copies (Fig. 2, lane 7), comparable to the nested PCR (10 copies; Fig. 2, lane 15). The standard curve for LAMP was generated from the amplification plots of the 10 -fold serial dilutions of the recombinant plasmids $\left(10^{7}\right.$ copies $/ \mu$ lo 10 copies $\left./ \mu l\right)$ vs. time ( $\mathrm{min})$ (Fig. 3a). A linear regression line with a coefficient of $r^{2}=0.97$ was plotted for the LAMP (Fig. 3b).

PCV1 DNA was detected in three commercial CSFV vaccines by the LAMP and the nested PCR (Table 2). These vaccines were manufactured by three different commercial companies (B, C, and E). All extracted DNA of tested vaccine samples were spiked with PCV1 recombinant plasmids and yielded positive results for detection of PCV1 DNA by the LAMP (data not shown). These results also indicated that inhibition was not observed in the extracted DNA of 25 commercial swine vaccine samples.

\section{Discussion}

The LAMP developed in this study was rapid for the detection of PCV1 DNA. The products generated by this method can be analyzed not only by conventional agarose gel electrophoresis but also spectrophotometry, which enables real-time analysis and quantification of the amplicons in commercial swine vaccines. Amplification of a specific genomic region by conventional or nested PCR alone, or by PCR in combination with gene sequencing, has long been used to confirm the accuracy of amplicons generated by PCR (Muhling et al. 2006; Victoria et al. 2010). However, with or without gene sequencing, con-
Fig. 1 Analytical specificity of the LAMP was observed using agarose gel electrophoresis. Lane $M$ 2,000-100 bp ladder marker (50 U/ $\mu$; Protech, Taiwan); lanes 1-7 extracted DNA of PCV1, PCV2, PPV, PRV, cDNA of CSFV, PRRSV, and negative control, respectively

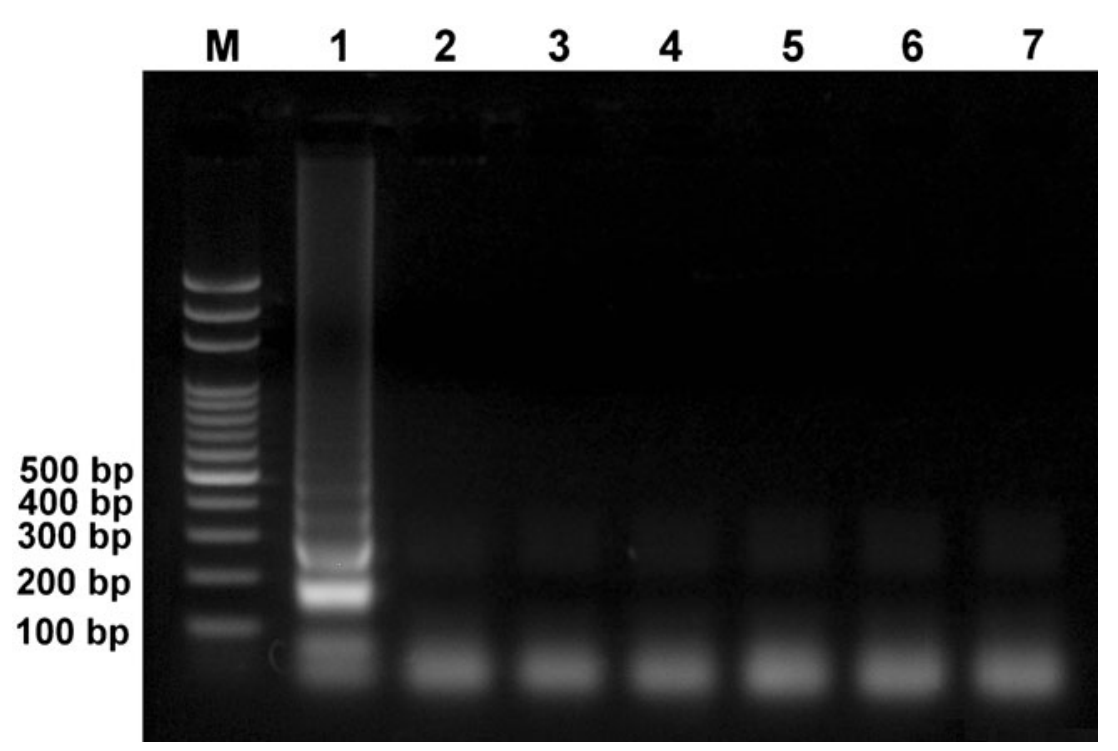




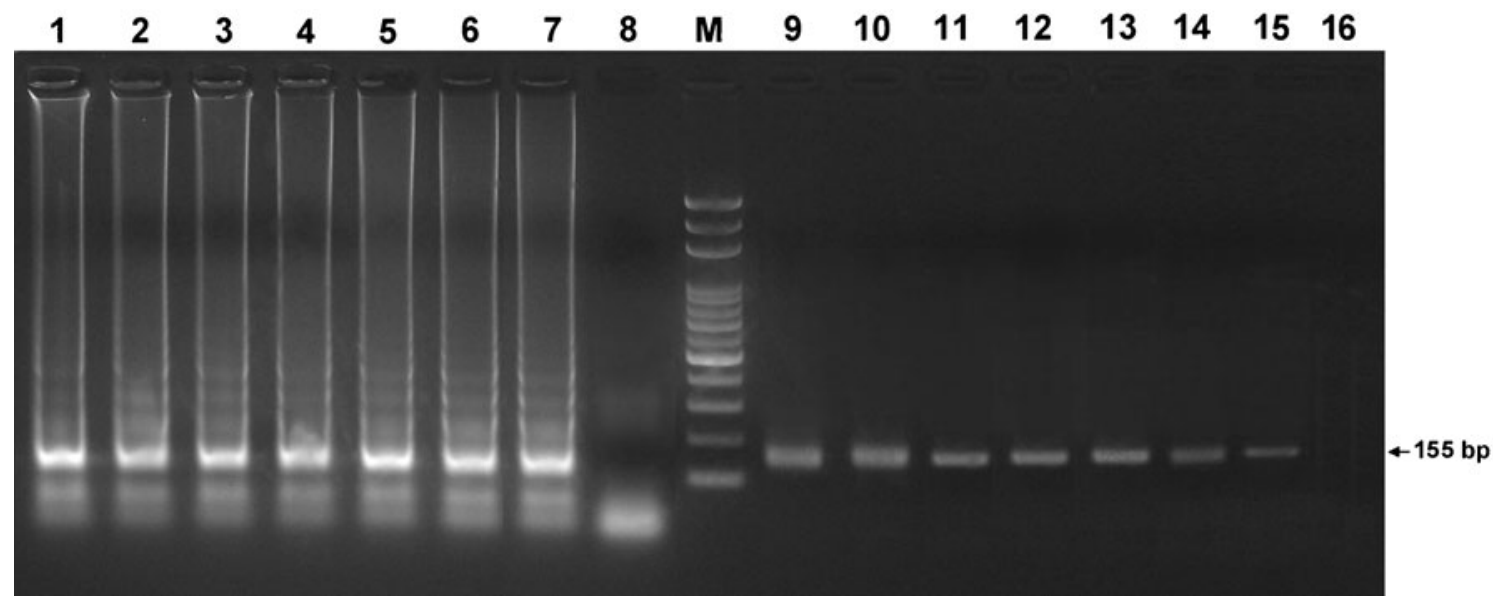

Fig. 2 Analytical sensitivities of the LAMP (lanes 1-8) and the nested PCR (lanes 9-16) were compared by detecting 10-fold serial dilutions of the recombinant plasmid $\left(10^{7}\right.$ copies/ $\mu 1$ to 1 copy/ $\left.\mu 1\right)$ by agarose gel electrophoresis. Lane $M$ 2,000-100 bp ladder marker $(50 \mathrm{U} / \mu \mathrm{l}$; Protech, Taiwan). The PCR products of lanes 9-15 were 155 base pairs (bp) in length ventional detection procedures for PCV1 require several hours to complete. In contrast, DNA detection with the
LAMP was much faster than with conventional PCR or nested PCR. After preparation of the sample DNA, the
Fig. 3 Analytical sensitivity of the LAMP (a) was performed by real-time monitoring with 10 -fold serial dilutions of the recombinant plasmid: $10^{7}$ copies $/ \mu l$ to $1 \mathrm{copy} / \mu \mathrm{l}$ and negative control $(N T)$. The linear function fitted to the plot of the mean threshold time against the $\log$ of the input PCV1 the recombinant plasmid is also shown (b)

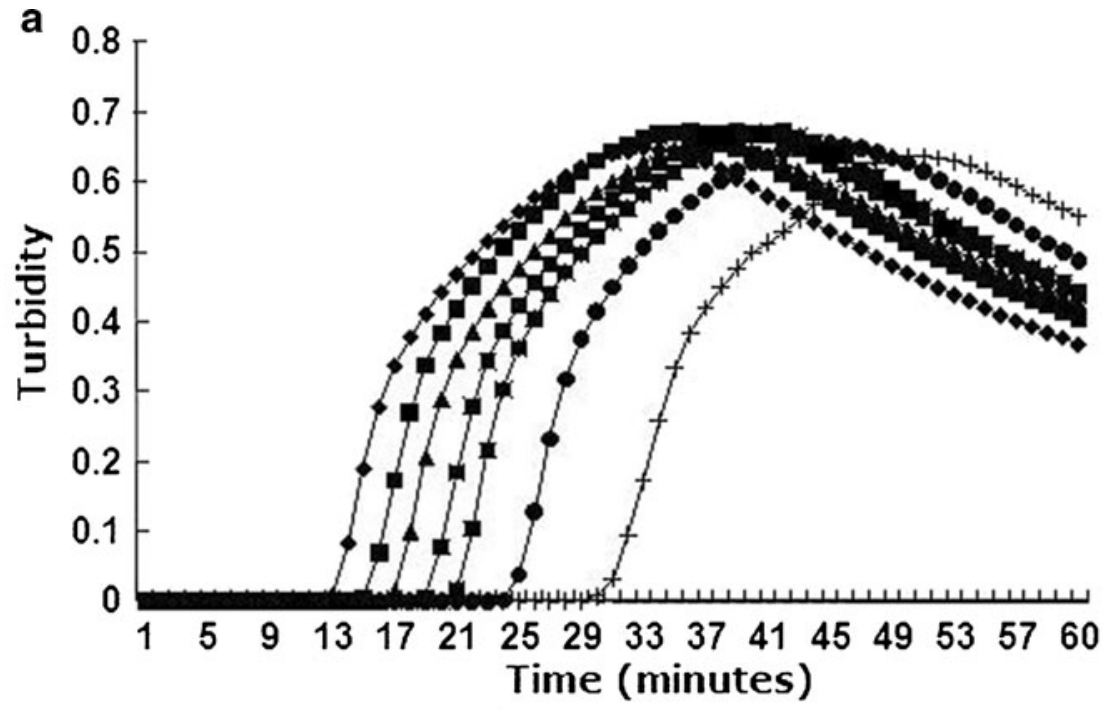

$\rightarrow-10^{7}$

$-10^{6}$

$-10^{5}$

$--10^{4}$

$-10^{3}$

$\rightarrow 10^{2}$

$+10^{1}$

$-1$ NT

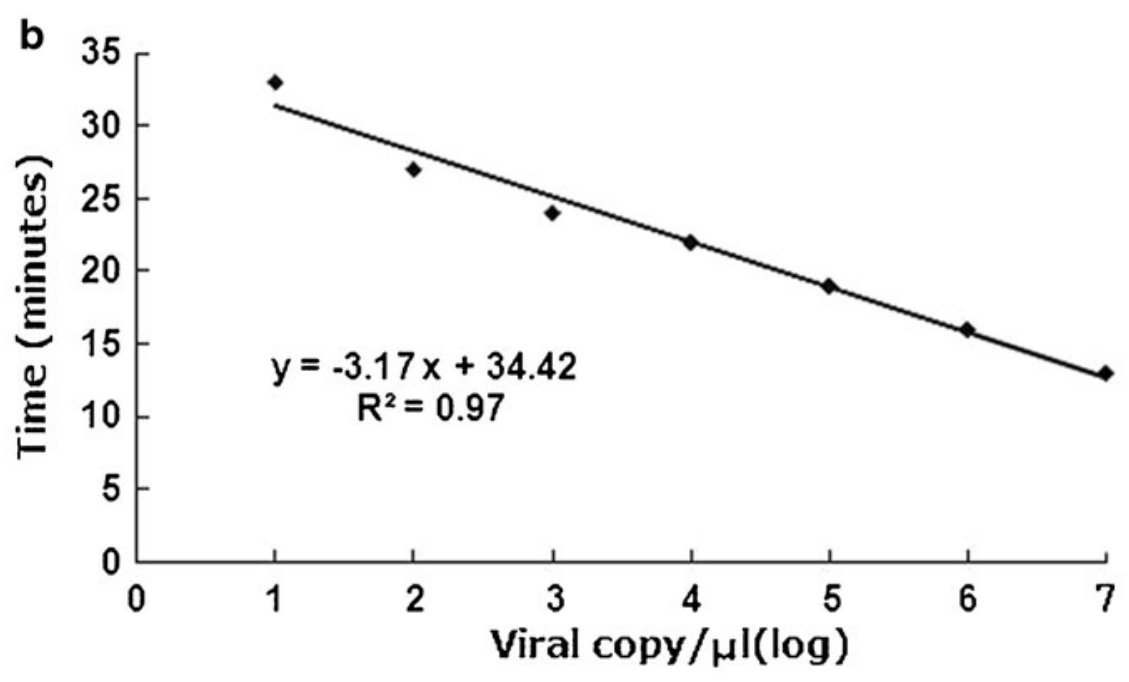


LAMP could be completed in approximately $1 \mathrm{~h}$, whereas other methods required several hours to a few days.

Furthermore, PCV1 DNA could be specifically and sensitively amplified using the two LAMP primer sets; no amplification was observed when the method was used to detect nucleic acids of PCV2, PPV, PRV, CSFV, FMDV, and PRRSV. These results indicate the specificity and wide applicability of our LAMP method in the detection of viral contaminants in commercial swine vaccines. The sensitivity of the LAMP was equivalent to that of the nested PCR. Our results showed that the LAMP is highly sensitive and can detect small amounts of PCV1 DNA present in samples. This method enables the detection and quantification of PCV1 DNA in commercial swine vaccines.

In this study, using the LAMP, we found that three commercially available CSFV vaccines were contaminated with PCV1 DNA, although the source of PCV1 DNA contamination in some commercial porcine vaccines has remained unknown. Recently, PCV1 DNA was also found in two commercial human rotavirus vaccines (Baylis et al. 2011; Victoria et al. 2010). Although PCV1 is not regarded as a potential pathogen in humans (Victoria et al. 2010), avoiding virus contamination during the process of vaccine production is absolutely essential. The detected PCV1 DNA may originate from the cell lines used for vaccine production (Quintana et al. 2006). Presence of PCV1 DNA in the vaccines does not necessarily imply that infectious PCV1 particles are present in the vaccines. The contaminating PCV1 may have been inactivated during the manufacturing process or may have been present in the live vaccine products in too small amounts to cause an infection (Quintana et al. 2006). Regardless of whether the contaminant PCV1 was alive or inactivated, the presence of viral DNA other than the vaccine DNA itself is absolutely unacceptable. To fulfill this requirement, a rapid, specific, and sensitive method such as LAMP can be easily incorporated in the production process to screen for PCV1 contamination in vaccines and in cell lines used for cultivation of the vaccine viruses.

The spiking study was performed by deliberately spiking PCV1 virus into the vaccine samples to account for inhibition; this avoids a potential problem that may result in the under-detection of PCV1 (i.e., false negatives). A previous study indicated that some human medicines contain heparin, adjuvant, phenol, or formaldehyde, which are common PCR inhibitors and always remain with the extracted nuclear acid (Yokota et al. 1999). In this study, no evidence of inhibition has been observed in any extracted DNA of swine vaccine sample for spiked recombinant plasmids. However, this was necessary to perform spiking studies as an internal control for the LAMP reaction; this assessed individual vaccine matrices that may be the cause of amplification product inhibition.
In conclusion, our LAMP method enables the detection of small amounts of PCV1 DNA. This method can be used to rapidly detect cell lines and commercial swine vaccines for PCV1 contamination with high sensitivity and specificity.

Acknowledgments The authors are grateful to those who submitted commercial porcine vaccines to Division of Hog Cholera Research, Animal Health Research Institute, Executive Yuan. The authors also thank Dr. Richard Huang and Dr. Eric Wang (Protech Technology Enterprise Co., Ltd., Taipei, Taiwan) for their excellent technical help.

Open Access This article is distributed under the terms of the Creative Commons Attribution Noncommercial License which permits any noncommercial use, distribution, and reproduction in any medium, provided the original author(s) and source are credited.

\section{References}

An D, Song DS, Park JY, Park BK (2009) A DNA miniarray system for simultaneous visual detection of porcine circovirus type 1 (PCV1) and 2 (PCV2) in pigs. Vet Res Commun 33:139-147

Alhassan A, Thekisoe OM, Yokoyama N, Inoue N, Motloang MY, Mbati PA, Yin H, Katayama Y, Anzai T, Sugimoto C, Igarashi I (2007) Development of loop-mediated isothermal amplification (LAMP) method for diagnosis of equine piroplasmosis. Vet Parasitol 143:155-160

Allan GM, McNeilly F, Cassidy JP, Reilly GA, Adair B, Ellis WA, McNulty MS (1995) Pathogenesis of porcine circovirus: experimental infections of colostrum deprived piglets and examination of pig foetal material. Vet Microbiol 44:49-64

Baylis SA, Finsterbusch T, Bannert N, Blümel J, Mankertz A (2011) Analysis of porcine circovirus type 1 detected in Rotarix vaccine. Vaccine 29:690-697

Calsamiglia M, Segalés J, Quintana J, Rosell C, Domingo M (2002) Detection of porcine circovirus types 1 and 2 in serum and tissue samples of pigs with and without postweaning multisystemic wasting syndrome. J Clin Microbiol 40:1848-1850

Chae C (2005) A review of porcine circovirus 2-associated syndromes and diseases. Vet J 169:326-336

Chen HT, Zhang J, Sun DH, Chu YF, Cai XP, Liu XT, Luo XN, Liu Q, Liu YS (2008) Rapid detection of porcine circovirus type 2 by loopmediated isothermal amplification. J Virol Methods 149:264-268

Cheung AK (2003) Transcriptional analysis of porcine circovirus type 2. Virology 305:168-180

Cságola A, Kiss I, Tuboly T (2008) Detection and analysis of porcine circovirus type 1 in Hungarian wild boars: short communication. Acta Vet Hung 56:139-144

de Castro AM, Cortez A, Heinemann MB, Brandão PE, Richtzenhain LJ (2008) Molecular diversity of Brazilian strains of porcine circovirus type 2 (PCV-2). Res Vet Sci 85:197-200

Dulac GC, Afshar A (1989) Porcine circovirus antigens in PK-15 cell line (ATCC CCL-33) and evidence of antibodies to circovirus in Canadian pigs. Can J Vet Res 53:431-433

Finsterbusch T, Steinfeldt T, Caliskan R, Mankertz A (2005) Analysis of the subcellular localization of the proteins Rep, Rep' and Cap of porcine circovirus type 1. Virology 343:36-46

Finsterbusch T, Mankertz A (2009) Porcine circoviruses-small but powerful. Virus Res 143:177-183

Han ET, Watanabe R, Sattabongkot J, Khuntirat B, Sirichaisinthop J, Iriko H, Jin L, Takeo S, Tsuboi T (2007) Detection of four Plasmodium species by genus- and species-specific loop-mediated isothermal amplification for clinical diagnosis. J Clin Microbiol 45:2521-2528 
Horlen KP, Schneider P, Anderson J (2007) A cluster of farms experiencing severe porcine circovirus associated disease: clini$\mathrm{cal}$ features and association with the PCV $2 \mathrm{~b}$ genotype. J Swine Health Prod 15:270-278

Huang YL, Pang VF, Pan CH, Chen TH, Jong MH, Huang TS, Jeng CR (2009) Development of a reverse transcription multiplex realtime PCR for the detection and genotyping of classical swine fever virus. J Virol Methods 160:111-118

Ihira M, Yoshikawa T, Enomoto Y, Akimoto S, Ohashi M, Suga S, Nishimura N, Ozaki T, Nishiyama Y, Notomi T, Ohta Y, Asano Y (2004) Rapid diagnosis of human herpesvirus 6 infection by a novel DNA amplification method, loop-mediated isothermal amplification. J Clin Microbiol 42:140-145

Kixmöller M, Ritzmann M, Eddicks M, Saalmüller A, Elbers K, Fachinger V (2008) Reduction of PMWS-associated clinical signs and coinfections by vaccination against PCV2. Vaccine 25:3443-3451

Lekcharoensuk P, Morozov I, Paul PS, Thangthumniyom N, Wajjawalku W, Meng XJ (2004) Epitope mapping of the major capsid protein of type 2 porcine circovirus (PCV2) by using chimeric PCV1 and PCV2. J Virol 78:8135-8145

Mankertz A, Caliskan R, Hattermann K, Hillenbrand B, Kurzendoerfer P, Mueller B, Schmitt C, Steinfeldt T, Finsterbusch T (2004) Molecular biology of Porcine circovirus: analyses of gene expression and viral replication. Vet Microbiol 98:81-88

Mahe D, Blanchard P, Truong C, Arnauld C, Le Cann P, Cariolet R, Madec F, Albina E, Jestin A (2000) Differential recognition of ORF2 protein from type 1 and type 2 porcine circoviruses and identification of immunorelevant epitopes. J Gen Virol 81:1815-1824

Muhling J, Raye WS, Buddle JR, Wilcox GE (2006) Genetic characterisation of Australian strains of porcine circovirus types 1 and 2. Aust Vet $\mathrm{J} 84: 421-425$
Nagashima S, Yoshida A, Ansai T, Watari H, Notomi T, Maki K, Takehara T (2007) Rapid detection of the cariogenic pathogens Streptococcus mutans and Streptococcus sobrinus using loopmediated isothermal amplification. Oral Microbiol Immuno 22:361-368

Notomi T, Okayama H, Masubuchi H, Yonekawa T, Watanabe K, Amino N, Hase T (2000) Loop-mediated isothermal amplification of DNA. Nucleic Acids Res 15:e63

Quintana J, Segalés J, Calsamiglia M, Domingo M (2006) Detection of porcine circovirus type 1 in commercial pig vaccines using polymerase chain reaction. Vet J 171:570-573

Tischer I, Mields W, Wolff D, Vagt M, Griem W (1986) Studies on epidemiology and pathogenicity of porcine circovirus. Arch Virol 91:271-276

Tischer I, Bode L, Peters D, Pociuli S, Germann B (1995) Distribution of antibodies to porcine circovirus in swine populations of different breeding farms. Arch Virol 140:737-743

Victoria JG, Wang C, Jones MS, Jaing C, McLoughlin K, Gardner S, Delwart EL (2010) Viral nucleic acids in live-attenuated vaccines: detection of minority variants and an adventitious virus. J Virol 84:6033-6040

Wang C, Huang TS, Huang CC, Tu C, Jong MH, Lin SY, Lai SS (2004) Characterization of porcine circovirus type 2 in Taiwan. J Vet Med Sci 66:469-475

Wang C, Lee F, Huang TS, Pan CH, Jong MH, Chao PH (2008) Genetic variation in open reading frame 5 gene of porcine reproductive and respiratory syndrome virus in Taiwan. Vet Microbiol 131:339-347

Yokota M, Tatsumi N, Nathalang O, Yamada T, Tsuda I (1999) Effects of heparin on polymerase chain reaction for blood white cells. J Clin Lab Anal 13:133-140 